\title{
ARTIKELPENELITIAN
}

\section{MORFOLOGI EOSINOFIL PADA APUSAN DARAH TEPI MENGGUNAKAN PEWARNAAN GIEMSA, WRIGHT, DAN KOMBINASI WRIGHT-GIEMSA}

\author{
${ }^{1}$ Rinny Ardina, ${ }^{2}$ Sherly Rosalinda \\ ${ }^{1}$ Dosen Program Studi D-III Analis Kesehatan Fakultas IImu Kesehatan \\ Universitas Muhammadiyah Palangkaraya \\ ${ }^{2}$ Mahasiswa Program Studi D-III Analis Kesehatan Fakultas IImu Kesehatan \\ Universitas Muhammadiyah Palangkaraya
}

\begin{abstract}
ABSTRAK
Pemeriksaan apusan darah tepi mampu menilai morfologi sel (eritrosit, leukosit, trombosit), menentukan jumlah dan jenis leukosit, mengestimasi jumlah trombosit dan mengidentifikasi adanya parasit. Pewarnaan Romanowsky adalah pewarnaan yang sering digunakan dan di Indonesia untuk mewarnai preparat apusan darah tepi digunakan pewarnaan Giemsa dan terkadang Wright atau kombinasi Wright-Giemsa. Dalam menilai kualitas apusan darah tepi digunakan penilaian terhadap morfologi eosinofil, karena eosinofil memiliki ciri yang khas, jumlahnya cukup banyak dan mudah diamati. Penelitian ini bertujuan untuk menggambarkan morfologi eosinofil pada apusan darah tepi dengan menggunakan pewarnaan Giemsa, Wright, dan kombinasi Wright-Giemsa. Dilakukan penelitian deskritif kualitatif dengan rancangan penelitian seran lintang (cross sectional study) pada 30 sampel yang diambil dengan teknik Simple Random Sampling. Sampel darah diwarnai dengan Giemsa, Wright, dan kombinasi Wright-Giemsa. Gambaran morfologi eosinofil dengan pewarnaan Giemsa menunjukkan inti sel berwarna biru keunguan dan granula tampak cukup jelas terlihat berwarna merah muda, dan apusan lebih tahan lama setelah disimpan. Pada pewarnaan Wright menunjukan inti sel dan granula tampak lebih jelas terlihat kemerahan dengan warna yang lebih menonjol dibandingkan dengan pewarnaan Giemsa namun kekurangan pewarna Wright yaitu tidak tahan lama dalam iklim tropis. Pada apusan dengan pewarnaan kombinasi Wright-Giemsa terdapat kelebihan dari setiap zat warna dimana granula, plasma dan inti lebih jelas terlihat dan pewarnaan lebih tahan lama disimpan. Namun, perlu diperhatikan juga tujuan dari pembuatan preparat apusan darah tepi, karena apabila ingin menentukan ada/tidaknya parasit akan lebih baik menggunakan pewarnaan Giemsa, sedangkan apabila ingin melihat morfologi basofil akan lebih baik menggunakan pewarnaan Wright.Kata Kunci: Eosinofil, Apusan Darah Tepi, Giemsa, Wright, Kombinasi Wright-Giemsa
\end{abstract}




\section{PENDAHULUAN}

Pemeriksaan preparat apus darah tepi merupakan bagian yang penting dari rangkaian pemeriksaan hematologi. Keunggulan dari pemeriksaan apus darah tepi ialah mampu menilai berbagai unsur sel darah tepi seperti morfologi sel (eritrosit, leukosit, trombosit), menentukan jumlah dan jenis leukosit, mengestimasi jumlah trombosit dan mengidentifikasi adanya parasit (Riswanto, 2013).

Tujuan dilakukannya pewarnaan pada preparat apus darah tepi yaitu agar memudahkan dalam melihat berbagai jenis sel dan juga dalam mengevaluasi morfologi dari sel-sel tersebut (Rodak, et al., 2007). International Council for Standardization in Haematology (ICSH) merekomendasikan metode pewarnaan Romanowsky karena pewarnaan ini mampu memberikan hasil memuaskan pada apusan darah tepi (Bain, 2014).

Beberapa pewarnaan yang termasuk dalam metode pewarnaan Romanowsky yaitu pewarnaan Wright, Giemsa, WrightGiemsa, Leishman, May-Grundwald dan pewarnaan Jenner. Pewarna Romanowsky mengandung pewarna kationik atau basa seperti (1) azure B yang dapat memberikan warna biru-ungu atau biru pada inti sel, nukleoprotein, granula basofil dan granula neutrofil, dan (2) pewarna anion atau asam, seperti eosin $Y$ dapat memberikan warna merah atau oranye pada eritrosit dan granula eosinofil serta mewarnai inti sel (McKenzie, 2014 ; Bain, 2014).

Di Indonesia, pewarnaan yang umum digunakan ialah pewarnaan Giemsa sebab Giemsa lebih tahan lama dalam iklim tropis. Beberapa klinik juga menggunakan pewarna Wright dalam mewarnai apusan darah tepi. Terkadang pewarnaan Giemsa juga dikombinasikan dengan Wright, dimana diharapkan kelebihan dari tiap-tiap zat warna Giemsa dan Wright bisa didapatkan dan akan menjadikan sediaan apus darah tepi lebih jelas terlihat secara mikroskopis dan jadi lebih tahan lama (Riswanto, 2013 ; Gandasoebrata, 2007).

Pada apusan darah tepi salah satu sel yang dapat diamati ialah leukosit. Leukosit memiliki sebuah inti yang bentuk dan ukurannya bervariasi sehingga mudah dibedakan dengan eritrosit dan trombosit. Terdapat 5 jenis leukosit yang utama, yaitu neutrofil, eosinofil, basofil, limfosit, dan monosit. Eosinofil merupakan salah satu jenis sel leukosit yang memiliki ciri-ciri khas diantaranya sel bulat, inti biasanya hanya memiliki 2 lobus, kromatin berwarna ungu, sitoplasma mengandung banyak granula eosinofilik (jingga) yang berukuran sama besar dan lebih besar dibandingkan granula neutrofil (Riswanto, 2013 ; Palmer, et al., 2015).

Dalam menilai kualitas apus darah tepi menggunakan pewarnaan Giemsa, Wright, 
dan kombinasi Wright-Giemsa digunakan penilaian terhadap morfologi eosinofil, karena eosinofil memiliki ciri yang khas, jumlahnya cukup banyak dan mudah diamati.

\section{METODE PENELITIAN}

\section{Jenis dan Rancangan Penelitian}

Jenis penelitian pada penelitian ini adalah deskritif kualitatif dengan rancangan penelitian seran lintang (cross sectional study) yang bertujuan untuk mengambarkan morfologi eosinofil pada apusan darah tepi menggunakan pewarnaan Giemsa, Wright dan kombinasi Giemsa-Wright (Sastroasmoro dan Ismael, 2011).

\section{Waktu dan Tempat Penelitian}

Penelitian dilaksanakan selama 2 bulan, yaitu mulai bulan Mei 2017 untuk penyusunan proposal hingga bulan Juni 2017 mendapatkan hasil penelitian. Penelitia n dilakukan di Laboratorium Kimia Klinik, Fakultas IImu Kesehatan, Universitas Muhammadiyah Palangkaraya.

\section{Populasi dan Sampel}

\section{Populasi}

Populasi dalam penelitian ini berjumlah

47 orang dari seluruh mahasiswa Analis Kesehatan Semester 4, Fakultas IImu Kesehatan, Universitas Muhammadiyah Palangkaraya.

\section{Sampel}

Sampel yang diperoleh dalam penelitian ini yaitu sebanyak 30 orang yang diambil dengan menggunakan teknik Simple Random Sampling yaitu pengambilan sampel dilakukan undian secara acak pada seluruh anggota populasi (Novita, dkk., 2015).

\section{Instrumen Penelitian}

\section{Alat}

Alat-alat yang digunakan dalam penelitian yaitu mikroskop CX 21, kaca objek, tabung vakum ungu (berisi K3EDTA), tourniquet, rak pengecatan, dan pipet tetes.

\section{Bahan}

Bahan-bahan yang digunakan antara lain Wright cair siap pakai, Giemsa Stock, metanol, buffer fosfat 6,4 , aquades, dan kapas alkohol $70 \%$.

\section{Prosedur Penelitian}

\section{Pengambilan Sampel Darah Vena}

a. Posisi lengan pasien harus lurus dan siku jangan membengkok. Dipilih lengan yang banyak melakukan aktivitas.

b. Pasien diminta untuk mengepalkan tangan.

C. Tourniquet dipasang $\pm 10 \mathrm{~cm}$ di atas lipat siku (tidak lebih dari 1 menit).

d. Dipilih bagian vena mediana cubiti.

e. Kulit pada bagian yang akan diambil darahnya dibersihkan 
dengan kapas alkohol $70 \%$ dan dibiarkan kering (jangan dipegang lagi).

f. Bagian vena tadi ditusuk dengan lubang jarum menghadap keatas dengan sudut kemiringan antara jarum dan kulit adalah $15^{\circ}$. Tabung vakum ditekan sehingga darah terisap ke dalam tabung.

g. Tourniquet dilepaskan dan pasien diminta untuk melepaskan kepalan tangan.

h. Biarkan darah mengalir ke dalam tabung sampai selesai.

i. Jarum ditarik lalu kapas alkohol $70 \%$ diletakkan di atas bekas tusukan untuk menekan bagian tersebut selama \pm 2 menit. Setelah darah berhenti, kemudian bagian ini diplester selama \pm 15 menit (Depkes $\mathrm{RI}, 2008$ ).

\section{Pembuatan Preparat Apus Darah Tepi}

Darah pada tabung vakum EDTA harus dikocok keatas dan kebawah agar plasma darah bercampur dengan sel-sel darah. Kemudian darah diambil menggunakan pipet tetes dan diteteskan pada preparat (obyek glass). Selanjutnya obyek glass diletakkan pada sudut $25^{\circ}-30^{\circ}$ pada tetesan darah, kemudian ditarik lurus sampai ujung preparat (Zilvanhisna, 2017).

\section{Pewarnaan Preparat Apus Darah Tepi dengan Giemsa 10\%}

a. Meneteskan metanol ke atas preparat dan dibiarkan selama 5 menit. Lalu sisa metanol dibuang.

b. Meneteskan larutan giemsa 10\% (sampai semua apusan tergenangi) dan dibiarkan selama 15 menit.

c. Preparat dibilas dengan air kemudian dikeringkan di udara (Priyana, 2010).

\section{Pewarnaan Preparat Apus Darah Tepi dengan Wright}
a. Meneteskan larutan Wright ke atas preparat (sampai semua apusan tergenangi)
b. Meneteskan larutan buffer $\mathrm{pH} 6,4$ (sampai semua apusan tergenangi) dan dibiarkan 5-12 menit.
c. Apusan dibilas dengan air dan bagian belakang apusan yang kotor dibersihkan dari sisa zat warna.
d. Preparat apus darah tepi dibiarkan kering di udara (Priyana, 2010).

\section{Pewarnaan Preparat Apus Darah Tepi dengan Kombinasi Wright- Giemsa}
a. Meneteskan larutan Wright ke atas preparat sampai semua apusan tergenangi, lalu dibiarkan selama 2 menit.
b. Menambahkan larutan Giemsa $10 \%$ sampai apusan tergenangi semua, lalu dibiarkan selama 15 menit.


c. Preparat dibilas dengan air kemudian dikeringkan di udara (Gandasoebrata, 2007).

\section{Pengolahan dan Analisis Data}

Analisis yang dilakukan yaitu analisis deskriptif kualitatif dimana gambaran morfologi eosinofil dan juga ketahanan lama penyimpanan preparat apus darah tepi dideskripsikan secara subjektif berdasarkan gambaran yang ditampilkan pada hasil penelitian.

\section{HASIL DAN PEMBAHASAN}

\section{Hasil}

Hasil gambaran morfologi eosinofil dengan menggunakan pewarnaan Giemsa, Wright dan kombinasi Giemsa-Wright dapat dilihat pada gambar berikut.

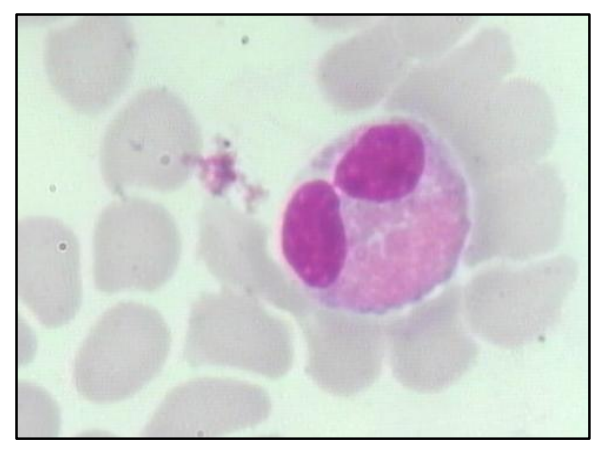

(a)

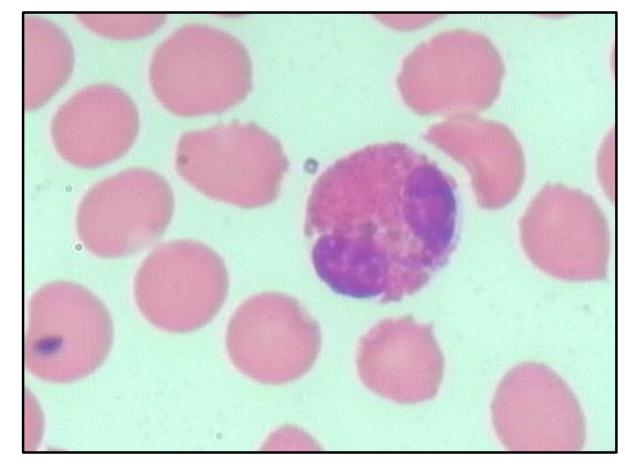

(b)

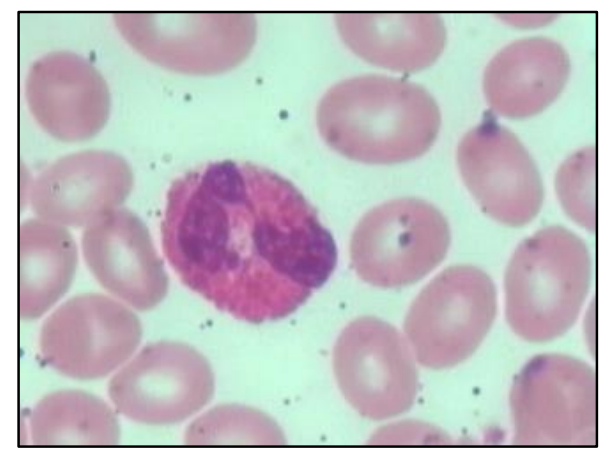

(c)

Gambar 1. (a) pewarnaan Giemsa $10 \%$,

(b) pewarnaan Wright, (c) pewarnaan

\section{Kombinasi Wright-Giemsa}

Gambaran morfologi eosinofil yang diwarnai dengan tiga pewarnaan berbeda menunjukkan kualitas dan kuantitas warna yang berbeda pula.

Apabila ditinjau dari ketahanan lama penyimpanan preparat apus darah tepi dari penggunaan ketiga pewarnaan tersebut, diperoleh gambaran sebagai berikut.

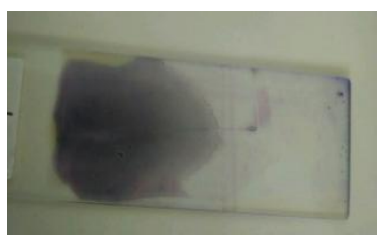

(a)

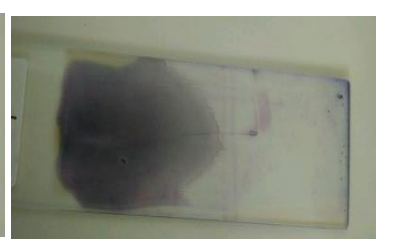

(b)

\section{Gambar 2. Ketahanan Preparat dengan} Pewarnaan Giemsa $10 \%$

(a) Setelah dicat dengan pewarnaan Giemsa 10\%, (b) Pewarnaan Giemsa setelah disimpan 5 hari. 


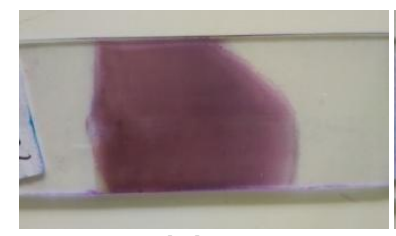

(a)

(b)

Gambar 3. Ketahanan Preparat dengan Pewarnaan Wright

(a) Setelah dicat dengan pewarnaan Wright, (b) Pewarnaan Wright setelah disimpan 5 hari.

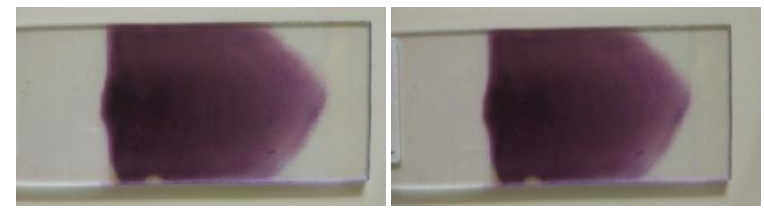

(a)

(b)

Gambar 4. Ketahanan Preparat dengan

Pewarnaan Wright

(a) Setelah dicat dengan pewarnaan kombinasi, (b) Pewarnaan Wright-Giemsa setelah disimpan 5 hari.

\section{Pembahasan}

Berdasarkan hasil pengamatan secara mikroskopis pada apusan darah tepi yang sudah diwarnai menggunakan pewarnaan Giemsa, Wright dan kombinasi WrightGiemsa, didapat hasil yang menunjukan perbedaan pada warna granula dan inti sel eosinofil, serta perbedaan ketahanan lama penyimpanan preparat apus darah tepi.

Pada gambar 1 (a) nampak gambaran morfologi eosinofil dengan pewarnaan Giemsa $10 \%$ menunjukkan warna granula yang cukup jelas terlihat yaitu berwarna merah muda dengan inti sel yang berwarna biru keunguan. Namun apabila dibandingkan dengan gambaran morfologi eosinofil dengan pewarnaan Wright pada gambar 1 (b), nampak warna granula yang jauh lebih menonjol yaitu berwarna kemerahan dengan inti berwarna kebiruan dibandingkan hasil dengan pewarnaan Giemsa $10 \%$. Pewarnaan dengan kombinasi Wright-Giemsa pada gambar 1 (c) menunjukkan kelebihan dari setiap zat warna dimana granula dan inti eosinofil terwarnai dengan sangat baik dan menonjol.

Apabila ditinjau dari segi ketahanan lama penyimpanan preparat apus darah tepi, pewarnaan Wright memiliki kekurangan yaitu tidak tahan lama dalam iklim tropis hal ini terlihat pada gambar 3 dimana pewarnaan Wright setelah diwarnai memang nampak lebih tegas, akan tetapi setelah disimpan selama lima hari warnanya semakin memudar dari sebelumnya. Hal ini berbeda dengan preparat yang diwarnai dengan Giemsa $10 \%$ seperti yang terlihat pada gambar 2 , dimana tidak terdapat perubahan warna pada apusan darah tepi baik setelah diwarnai maupun setelah lima hari penyimpanan. Begitu pula dengan pewarnaan dengan kombinasi WrightGiemsa seperti pada gambar 4, dimana tidak terdapat perubahan kualitas pewarnaan baik setelah diwarnai maupun setelah disimpan selama lima hari.

Di Indonesia, pewarnaan yang umum digunakan untuk mewarnai apus darah tepu adalah Gimesa. Giemsa sangat baik untuk mengidentifikasi berbagai sel granulosit dan 
sel-sel darah lainnya, menghasilkan gambaran inti yang jelas, sangat baik dalam membedakan komponen basofilik atau eosinofilik dari sel limfoid dan mieloid, dan keunggulan utama Giemsa ialah lebih tahan lama dalam iklim tropis dan sangat baik untuk mempelajari parasit-parasit darah (Barcia, 2007; Riswanto, 2013). Oleh sebab itu, eosinofil yang terwarnai dengan Giemsa memberikan hasil yang representatif dengan warna granula oranye-merah dan preparat apus darah tepi juga dapat bertahan dengan baik pada iklim tropis Indonesia.

Penggunaan pewarna Wright di Indonesia disebabkan Wright telah mengandung metil alkohol dalam konsentrasi tinggi, sehingga tidak perlu dilakukan fiksasi. Kelebihan dari pewarnaanWright yaitu plasma dan inti sel lebih jelas terlihat. Hal itu disebabkan karena komposisi dari Wright, yang terdiri dari methylene blue yang akan memberi warna biru pada inti (nukleus) yang mengandung DNA dan eosin yang memberi warna merah pada sitoplasma. Sedangkan kekurangan pewarna Wright yaitu tidak tahan lama dalam iklim tropis (Freund, 2012; Kiswari, 2014).

Pewarnaan Wright-Giemsa merupakan modifikasi pewarnaan Romanowsky yang mengandung kombinasi zat warna basa seperti methylene blue dan produk oksidatifnya, azure A dan azure B, dan zat warna asam seperti eosin. Pewarnaan ini sudah rutin digunakan di laboratorium hematologi untuk mewarnai apusan darah tepi dan sumsum tulang. Teknik pewarnaan dengan Wright-Giemsa diketahui baik untuk menilai morfologi eosinofil-neutrofil-basofil, dan Wright untuk basofil, sedangkan Giemsa untuk parasit-parasit dalam darah (Barcia, 2014 ; Sudiro, dkk., 2010).

\section{KESIMPULAN}

Gambaran morfologi eosinofil dengan pewarnaan Giemsa menunjukkan inti sel berwarna biru keunguan dan granula tampak cukup jelas terlihat berwarna merah muda, dan apusan lebih tahan lama setelah disimpan. Pada pewarnaan Wright menunjukan inti sel dan granula tampak lebih jelas terlihat kemerahan dengan warna yang lebih menonjol dibandingkan dengan pewarnaan Giemsa namun kekurangan pewarna Wright yaitu tidak tahan lama dalam iklim tropis. Pada apusan dengan pewarnaan kombinasi Wright-Giemsa terdapat kelebihan dari setiap zat warna dimana granula, plasma dan inti lebih jelas terlihat dan pewarnaan lebih tahan lama disimpan. Namun, perlu diperhatikan juga tujuan dari pembuatan preparat apusan darah tepi, karena apabila ingin menentukan ada/tidaknya parasit akan lebih baik menggunakan pewarnaan Giemsa, sedangkan apabila ingin melihat morfologi 
basofil akan lebih baik menggunakan pewarnaan Wright.

\section{DAFTAR PUSTAKA}

Bain, B.J.. 2014. Blood cells: a practical guide. John Wiley \& Sons.

Barcia, J.J. 2007. The Giemsa Stain: Its History and Applications. International Journal of Surgical Pathology. 15 (3) : 292296.

Departemen Kesehatan Republik Indonesia (DEPKES RI). 2008. Pedoman Praktek Laboratorium yang Benar (Good Laboratory Practice). Departemen Kesehatan Republik Indonesia, Jakarta.

Freund, M. H. 2012. Atlas Hematologi : Praktikum Hematologi dengan Mikroskop, Edisi 11. Kedokteran EGC, Jakarta.

Gandasoebrata R. 2007. Penuntun Laboratorium Klinik. Dian Rakyat, Jakarta.

Kiswari, R. 2014. Hematologi dan Transfusi. Elangga, Jakarta.

McKenzie, S.B. 2014. Clinical Laboratory Hematology. Pearson Education Inc, New Jersey.

Novita L., R. Andriyani, dan M. Megasari. 2015. Buku Ajar Metodologi Penelitian Kebidanan. Deepublish, Sleman.

Palmer, L., C. Briggs, S. McFadden, G. Zini, J. Burthem, G. Rozenberg, M. Proytcheva, and S. J. Machin. 2015. ICSH Recommendations for The Standardization of Nomenclature And Grading of Peripheral Blood Cell Morphological Features. International Journal of Laboratory Hematology. 37 (3) : 287-303.
Priyana, A. 2010. Patologi Klinik Untuk Kurikulum Pendidikan Dokter Berbasis Kompetensi. Jakarta. Universitas Trisakti.

Riswanto. 2013. Pemeriksaan Laboratorium Hematologi. Alfamedia dan Kanal Medika, Yogyakarta.

Rodak, B.F., George, A. F, and Kathryn, D. 2007. Hematology: Clinical Principles and Applications. Sanders Elsevier. USA.

Sastroasmoro, S., dan Ismael, S. 2011. Dasar-dasar Metodologi Penelitian Klinis, Edisi Ke-4. Sagung Seto, Jakarta.

Sudiro, M., T. H. S. Madiadipoer, dan B. Purwanto. 2010. Eosinofil Kerokan Mukosa Hidung Sebagai Diagnostik Rinitis Alergi. Majalah Kedokteran Bandung. 42 (1) :1-6.

Zilvanhisna E. F. 2017. Klasifikasi Trombosit Pada Citra Hapusan Darah Tepi Berdasarkan Gray Level Co-Occurrence Matrix Menggunakan Backpropagation. Institut Teknologi Sepuluh Nopember. Surabaya. 